\title{
EVALUATION OF HEARING IN PATIENTS WITH BETA THALASSEMIA MAJOR
}

\author{
Ahmed Fadhil Hasan*, Husam Haider Salman ${ }^{\#}$ \& Jaafar Muhsen \\ Khalaf $^{\circledR}$ \\ *MB, ChB, FICMS, CABS ENT HNS, ENT Senior Surgeon at Al Shafaa General Hospital. "FRCS, DLO. \\ Retired, Department Of Surgery, College Of Medicine, Basrah University. ${ }^{@}$ MB,ChB, FICMS ENT, ENT \\ Surgeon, Basrah Teaching Hospital, Basrah, IRAQ.
}

\begin{abstract}
This prospective study was conducted in Basrah Teaching Hospital to evaluate the hearing of $\beta$ thalassemia major patients, and to find the association between desferoxamine (DFO) therapy and hearing loss $(\mathrm{HL})$.

Pure tone eudiometry (PTA) and tympanometry was done to determine hearing thresholds of (23) $\beta$ thalassemia major patients and (50) non thalassemic subjects. All subjects were more than 4 year old to allow PTA to be done. The criteria of evaluation included a full otological history, drug history, otological examination, audiological evaluation using PTA and tympanometry.

This study found that (6) out of (23) thalassemic patients and (6) out of (50) non thalassemic patients have hearing loss. From those thalassemic patients with HL, (5) patients have conductive hearing loss $(\mathrm{CHL})$ and one have sensorineural hearing loss (SNHL), while the non thalassemic patients with $\mathrm{HL}$ all have $\mathrm{CHL}$, also we found that (3) out of (5) thalassemic patients not on desferoxamine therapy have HL.

In conclusion, $\beta$ thalassaemia major has no significant statistical association with hearing problems, and there is no significant statistical association between desferoxamine therapy and hearing loss.
\end{abstract}

\section{Introduction}

$\mathrm{T}$ he first branchial arch contributes Meckel's cartilage, which includes the malleus head and neck, incus body and short process, and anterior malleolar ligament. It also contributes the tensor tympani and the first three hillocks of His. The second branchial arch contributes Reichert's cartilage, which includes the manubrium of the malleus, the long process of the incus, and most of the stapes. It also contributes the last three Hillocks of His. the first branchial pouch contributes the Eustachian tube, mastoid air cells, and inner layer of the tympanic membrane. The first branchial cleft contributes the external auditory canal (EAC) and outer layer of the tympanic membrane ${ }^{1-3}$. Bony labyrinth developed from otic capsule which encapsulates the otocyst that's later on forms the membranous labyrinth ${ }^{4}$.

The external ear consists of pinna and external auditory canal which divided into cartilaginous and bony parts. the tympanic membrane separates the external from the middle ear by its three layers. The tympanic cavity is an air-containing cavity in the petrous part of the temporal bone contains the ossicular chain with its associated muscles, the aperture of the Eustachian tube, and vascular system ${ }^{5-7}$.

The cochlea is a coiled bony tube, snailshaped makes about 2.5 turns in the temporal bone. It is divided into three compartments; the scala tympani, scala vestibule, and scala media. 
The organ of Corti is a complex sense organ that contains inner and outer hair cells and supporting cells resting on the basilar membrane in the scala media ${ }^{8-10}$.

Thalassaemia is the name given to a globin gene disorder that results in a diminished rate of synthesis of one or more of the globin chains and, consequently, a reduced rate of synthesis of the hemoglobin or hemoglobin's of which that chain constitutes a part. Thalassaemia may result from the deletion of a large part or all of a gene (as is usual in $\alpha$ thalassaemia) or from a small deletion or other mutation of a gene (as is usual in $\beta$ thalassaemia)

The thalassemias can be classified at different levels. Clinically, it is useful to divide them into three groups: the severe transfusion-dependent (major) varieties; the symptomless carrier states (minor); and a group of conditions of intermediate severity that fall under the loose heading "thalassemia intermedia"

Those children with $\beta$ thalasemia major usually become symptomatic from progressive hemolytic anemia with profound weakness and cardiac decompensation during the second 6 months of life if not treated. Transfusion therapy promotes general health and wellbeing and avoids the consequences of ineffective erythropoiesis. Iron overload is inevitable. Deferoxamine chelates iron and some other divalent cations, allowing their excretion in the urine and the stool if used appropriately ${ }^{11-13}$.

Types of hearing loss; Conductive hearing loss (CHL): can be caused in external and or middle ear disease, Sensorineural hearing loss (SNHL): the sensory component of the cochlea, acoustic nerve, brain stem or cortex is damaged, Mixed hearing loss: the conduction of sound to the cochlea is impaired, as is the transmission through the cochlea to the cortex ${ }^{14,15}$.

\section{Patients and methods}

This is a prospective study conducted on (73) subjects attending the ENT department in Basrah Teaching Hospital, (23) patients have been previously diagnosed as $\beta$ thalassaemia major were transferred from the thalassemic center in Basrah, while the remaining (50)subjects were non thalassemic selected randomly.

All the patients were subjected to the same questionnaire, clinical and audiological examinations. Patients were more than 4 year of age (to allow for pure tone audiometry to be done)

The questionnaire form included:

- Full otological history regarding: otalgia, otorrhoea, hearing impairment, itching, tinnitus, vertigo and others

- Family history of congenital hearing defect or haemoglobinopathies.

- Age at diagnosis of $\beta$ thalassaemia major

- Frequency of blood transfusion

- Desferal treatment:

1 - age at starting treatment

2- dose

3- frequency/week

All the patients were examined clinically by otoscope and tuning fork test $(512 \mathrm{~Hz}$, $\mathrm{C} 1$ ), then evaluated by pure tone audiometry and tympanometry.

They were divided into four groups according to the presence of hearing loss and whether they are thalassemic or not.

The instruments used were:

1. Otoscope.

2. $512 \mathrm{~Hz}, \mathrm{C} 1$ tuning fork

3. Audiometer:DA65R,GN.Otometer AS, DK-263 OTASTRUP, Denemark.

4. Tympanometer : DANPLEX, tymp 87 , clinical middle ear analyzer 


\section{Results}

Table I shows that most of the patients in this study are in the age group 1 (age 4-14 years), males are more than female, in regarding to the thalassemic patients.

Table I: Distribution of $\boldsymbol{\beta}$ thalassaemic major patients according to age and gender

\begin{tabular}{|c|c|c|c|c|}
\hline Groups & Age & Male & Female & Total \\
\hline 1 & 4-14 years & 8 & 8 & 16 \\
\hline 2 & 15-24 years & 5 & 1 & 6 \\
\hline 3 & >24 years & 1 & 0 & 1 \\
\hline Total & & 14 & 9 & 23 \\
\hline
\end{tabular}

Table II shows that group 1 (ages 4-14 years) are more than other age groups in this study, the male more than female, in regarding non thalassemic subjects.

Table II: Distribution of non thalassemic patients according to the age and sex:

\begin{tabular}{|c|c|c|c|c|}
\hline Groups & Age & Male & Female & Total \\
\hline 1 & 4-14 years & 20 & 17 & 37 \\
\hline 2 & 15-24 years & 6 & 4 & 10 \\
\hline 3 & $>24$ years & 2 & 1 & 3 \\
\hline Total & & 28 & 22 & 50 \\
\hline
\end{tabular}

Table III shows that 6 out of 23 thalassemic patients (26\%) have HL, and 6 out of the 50 non thalassaemic patients $(12 \%)$ have HL

Table III: Distribution of the patients according to the hearing loss:

\begin{tabular}{|l|c|c|c|}
\hline & Patients with HL & Patients with no HL & Total \\
\hline B thalassaemic major patients & 6 & 17 & 23 \\
\hline Non thalassaemic patients & 6 & 44 & 50 \\
\hline Total & 12 & 61 & 73 \\
\hline
\end{tabular}

Table IV show that 5 out of $23(21 \%)$ of thalassemic patients have CHL, and 1 out of $23(4.3 \%)$ have SNHL, and 6 out of $50(12 \%)$ of non thalassaemic patients have CHL.

Table IV: Distribution of patients according to the type of hearing loss :

\begin{tabular}{|l|c|c|c|c|}
\hline & Normal hearing & CHL & SNHL & Total \\
\hline B thalassaemic major patients & 17 & 5 & 1 & 23 \\
\hline Non thalassaemic patients & 44 & 6 & 0 & 50 \\
\hline Total & 61 & 11 & 1 & 73 \\
\hline
\end{tabular}

Table V show that 3 out of 5 patients not on desferoxamine having HL ( $60 \%$ ).

Table V: Distribution of $\beta$ thalassemia major patients according to desferoxamine therapy

\begin{tabular}{|l|c|c|c|}
\hline & Patients with HL & Patients with no HL & Total \\
\hline Patients on desferoxamine & 3 & 15 & 1 \\
\hline Patients not on desferoxamine & 3 & 2 & 5 \\
\hline Total & 6 & 17 & 23 \\
\hline
\end{tabular}




\section{Discussion}

According to the results shown in tables III and IV, the hearing loss is more common in $\beta$ thalassaemia major patients than in non thalassaemic patients, and the conductive loss is more common than sensorineural type in the former group.

In table $\mathrm{V}$, the number of patients on desferoxamine therapy was more than patients not on desferoxamine, and the later group have more hearing loss than the former group.

The data shown in table III were statistically analyzed using odds ratio to find the association between the disease and the suspected risk factor and chisquare test to find statistical significance or relation between two qualitative variables, the result was no statistical significance or relation between the $\beta$ thalassaemia major and hearing loss ( $>00.05)$.

The data shown in table $\mathrm{V}$ were statistically analyzed using odds ratio to find the association between the disease *hearing loss* and the suspected risk factor *desferoxamine exposure*, the result found no association between the hearing loss and desferoxamine exposure. The findings in our study shared with the following studies:

Ambrosetti et al (2000) have been studied $57 \beta$ thalassaemia major patients over 3 years, he found that there was no significant difference between thalassaemic and non thalassaemic patient of same age; desferoxamine treatment seems to be non ototoxic when employed at the present dosage ${ }^{16}$.

Mojabi (2001) have been studied 65 thalassemic patients and 65 non thalassemic, and found that the hearing loss in thalassemic patients was 2.2 times higher than the control group, the type of hearing loss was totally conductive ${ }^{17}$.

Bibi shahin shamsian et al (2008) have been studied 67 patients over 5 years, he found that there were no significant difference between SNHL and non SNHL in patient age, sex, serum ferritine level, it seems that SNHL is not directly related to serum ferritin level or desferoxamine dosage and other factors ${ }^{18}$.

In contrast, Kontzoglou et al (1996) studied 88 patients over 6 years, this study confirms that desferoxamine induced auditory neurotoxicity and the necessity of periodical audiological control of $\beta$ thalassaemia major patient ${ }^{19}$.

Albera et al had obtained the results of audiometric screening of 153 children aged $5-18$ years affected by $\beta$ thalassemia and treated with regular transfusion and desferal therapy, they found that $38 \%$ of the patients having SNHL at higher frequencies, and CHL was not more than in patients with outthalassemia ${ }^{20}$.

Nezameddin Berjis et al (2003) have been evaluated $190 \quad \beta$ thalassemia major patients for otorhinolaryngological manifestations, they found that $3.5 \%$ have clinical hearing loss and 50\% having $\mathrm{SNHL}^{21}$.

The reason for the difference between this study and studies done by (Umbrosetti, Mojabi, and Shamsian) and other studies (Kontzoglou, Albera, Nezamaddin), is probably due to the higher dose and longer duration of treatment with desferoxamine in the latter studies.

\section{Conclusion and recommendation}

The $\beta$ thalassaemia major has no significant statistical association with hearing problems, and there is no significant statistical association between desferoxamine therapy and hearing loss.

A larger study is required to clarify the controversy between different studies about this problems, until then hearing evaluation of $\beta$ thalassaemia major patients taking desferoxamine and those not taking desferoxamine by audiometry is recommended because of the importance of this complication if it happens and the subsequent disabilities. 


\section{References}

1. Wareing Michael, J.Lalwani, Anil K. and Jackler Robert K. Development of the ear. Byron -Baily Head \& Neck surgery.4th edition. 2006. Lippincott Williams \& Wilkins publishers. pg; 1869-1872.

2. Van De Water, Thomas R. and StaeckerHinrich. Embryology of the outer, middle and inner ear. otolaryngology : Basic science and clinical review. 2006. Thieme Medical publishers, Inc. pg : 251.

3. Sadler T. W. and Bridges Twin. Langman,s Medical Embryology. 9th edition 2004. Pgs: 407-09.

4. Pasha R., Bojrab I., AhsanSyed, and Burgio L. Anatomy and embryology of the inner ear. Otolaryngology, Head and Neck surgery, clinical reference guide. 2000. Singular/Thomson learning publishers. pg : 287.

5. Oghalai S. John and Brownell E. William. Anatomy and physiology of the ear. Current diagnosis and treatment, otolaryngology, head and neck surgery. 2nd edition, 2007. McGraw Hill companies publishers. pgs :613-17.

6. Mills John H, KhariwalaSamir S. and Weber Peter C. anatomy and physiology of hearing. Byron - Baily Head and Neck surgery. 4th edition. 2006. Lippincott Williams and Wilkins publishers. Pgs : $1883-1899$.

7. Snell Richard S. Clinical anatomy by regions. 8th edition. 2007. Lippincott Williams and Wilkins publishers. pg: 706.

8. Gacek Richard R. and Gacek Mark R. anatomy of the auditory and vestibular system. Ballenger,sotorhinolaryngology, Head and neck surgery. 16th edition. 2003. BC Decker Inc. pg : 3-10.

9. Murrow, Bruce W. anatomy and physiology of the ear. ENT secretes. 3rd edition. 2005. Elesvier publishers. $\mathrm{pg}: 21$.

10. Manner, Albert L,. A pocket guide to the ear. 2003. Thiemeflexibook publishers. pg : 13.

11. Barbara J. Bain, Haemoglobinopathy Diagnosis, second edition, 2006, Black well publishing. pgs : $63,111-$ 112.

12. Nancy F. Olivieri and David J. Weatherall, Robert J. Arceci., lan M. hann., Owen P. Smith., Pediatric Hematology, 3rd edition. 2006. Black well publishing. pg : 283.

13. Michael R. DeBaun Elliott Vinchinsky, Kliegman : Nelson Textbook of Pediatrics, 18th edition, 2008. Saunders, An Imprint of Elsevier pg : 462. 9.

14. P. D. Bull, lecture notes on Diseases of the ear, nose, and throat, ninth edition, 2002., Black Well science publishing., pg: 11.

15. Gabbad A. Sandra and Uhler Kristin. Hearing evaluation. ENT Secretes. third edition. 2005. Elesvier publishers. pg : 24.

16. U. Ambrosetti, E. Donde, G. Piatti., M. D. Cappellini., Audiological evaluation in adult beta - thalassemia major patients under regular chelation treatment. Pharmacological Research, volume 42, issue 5 , November 2000 , pages $485-487$.

17. M.A.MOJABI M.D., evaluation of hearing loss in 65 thalassemic patients, the journal of Qazvin university of Medical Sciences, 2001.

18. BibiShahin Shamsian; Ali Aminasnafi ; HabiballahMoghadassian, Sensory neural hearing loss in beta thalassemia major patients treated with desferoxamine., Pediatric Hematology and Oncology, volume 25, issue 6 , august 2008 , pages $502-508$.

19. G. Kontzoglou, A.Koussi, J. Tsatra, G. Noussios, V. Vital, G. Sagarakis and M.Athanassiou., Sensorineural hearing loss in children with beta - thalassemia major in Northern Greece., International Journal of pediatric Otorhinolaryngology, volume 35, issue 3, may 1996, pages 223 - 230.

20. R. Albera, F. Pia, B. Morra, M. Lacilla, L. Bianco, V. Gabutti and A. Piga, Hearing loss and desferoxamine in homozygous beta thalassemia, International journal of audiology, 1988, volume 27, no. 4, pages $207-214$.

21. Nezameddin Berjis, Seied Mahdi Sonbolestan, Shadman Nemati, Farhad Mokhtarinejad, Zahra Danesh, Zahra Abdeyazdan, otorhinolaryngologic manifestation in thalassemia major patients, IRAN J PED, volume 17, no. 1, mar. 2007. 